\title{
Negotiating sustainability across scales
}

\section{Community organizing in the Outer Hebrides}

\author{
Jaspal Naveel Singh \& Tom Bartlett \\ Cardiff University, Wales
}

This paper represents voices of community organizers on Barra, a small island in the Outer Hebrides, Scotland. Although, arguably Barra is geographically and socio-politically located in the peripheries of Scotland, Britain and Europe, the island has been a center of North Atlantic maritime trade networks for centuries. In the current phase of Europeanization and devolution of powers within the United Kingdom, the community finds itself in the position of having to attend to multiple scales: the European Union, the United Kingdom, Scotland and the island itself with its various interest groups. We draw on ethnographic interviews with community organizers that were elicited for the research project Sustainability on the Edge to illustrate some political challenges and possibilities of such scalar realities. We show that community organizers construct a voice that emphasizes a historical quality of what it means to live on Barra while inflecting this quality with worldly knowledge that enables access to resources from outside the island. Our findings remind us that centers and peripheries are neither fixed categories that could simply be mapped on geographical visualizations nor notions independent of discursive practice.

Keywords: scales; multilevel governance; islands; voice; community organizing; devolution

\section{Introduction}

The island of Barra in the southern Outer Hebrides, 40 miles off the west coast of Scotland, is nine miles long by four wide. A 13-mile road edges around the coast and a further four-mile road takes you to the north end of the island, passing the Tràigh Mhór, the cockle strand on which the plane from Glasgow famously lands. Archaeological evidence suggests that Barra has been inhabited since perhaps 6000 BCE (Branigan \& Foster, 2002: 31), with a first peak of human activity between 3600 and 2700 BCE (Branigan \& Foster, 2002: 33-51). From the 9th to the 13th century CE the Outer Hebrides were part of the Norse Kingdom of 
the Isles and many villages and the most salient topographical features still bear names clearly derived from Norse. In 1266 control of the islands was transferred to Scotland, and in effect to local clan chiefs. In the case of Barra this meant the MacNeils, whose coat of arms bears a galley, or seafaring narrowboat, in testament to the clan's continuation of the Viking tradition of maritime trading and raiding. The clan system remained in force until the Jacobite wars in the early to mid-18th century, in the aftermath of which the British government sought to impose central rule and to undermine the system of affiliations which maintained the clan system. The economic decline of the Highlands and Islands in the ensuing period, culminating in the Clearances of the 18th and 19th centuries, remains a topic of fierce debate. For some, these were the inevitable results of population growth in unproductive areas, intensified by the Potato Famine, while for others, not least in the popular imagination, they are characterized as a brutal depopulation of the islands to make way for more profitable sheepfarming. Barra and the neighboring Uists suffered more than other areas, with 1700 islanders being transported to Canada in 1851 alone (Richards, 2013).

The island economy was revitalized through the fishing industry and Barra was a major herring port until the middle of the last century. Income from the sea, through fishing or service in the Merchant and Royal Navy, was necessary to supplement the largely subsistence economy of crofting (small-scale agriculture and sheep and cattle farming), which has always been precarious on the island's thin and rocky soil. The combination of these industries guaranteed relative selfsufficiency for the island community; but their decline over the last half-century resulted in a second period of out-migration and depopulation. Although the population is now relatively stable at around the 1200 mark, the demographic makeup within the island is shifting as the traditional cycle of in- and out-migration, whereby a large number of young islanders seek work at sea or on the mainland before returning with families, appears to be changing momentum (Euan Scott, Barra and Vatersay Community Council, pers. comm.). Life on the island is therefore more precarious than the population figures alone suggest as minor changes to the demographic and economic profile can have significant knock-on effects for the social systems underpinning island life.

These phases of Barra history reflect different conceptions of what is central and what is peripheral. As part of the sea-based kingdoms of the Vikings and the later Lords of the Isles, then as a herring port, Barra was central to the maritime economy of Europe, as symbolized by its prominent place in the maritime map that occupies a wall of the Doge's Palace in Venice (see also Stiùbhart, 2005). But, after the breakdown of the clan system, and again in modern times as momentum shifts from maritime to terrestrial centres of trade and administration, islands have become more dependent on resources and infrastructures coming from the 
mainland and central government, whose political games and economic flows can feel distant and irrelevant for the people of Barra. Nonetheless, within this system Barra is recognized as a well-organized and innovative community, with a history of community activism, including the establishment of the airport in 1936, the founding of Scotland's first féis (community cultural festival) in 1981 and, in recent years, the construction of a community-owned wind-turbine in Scurrival and mooring bays for tourist yachts in Castlebay. This activism is often accounted for in terms of the dynamic demographics of Barra when compared to other Hebridean islands. Poor farming land entailed travels across the globe with the Merchant and Royal Navy as well as migratory patterns to the terrestrial centers and back for education and employment. As a result many Barra folk have a firsthand knowledge of the workings of the terrestrial centers, and this informs their ideas on the sustainability of Barra as a socioeconomic community. These ideas are thus not born out of a narrow worldview or an ignorance of the world but out of dual and complex competences to understand what it means for Barra to sustainably enter the challenges of a global modernity shaped by policies and decisions from the terrestrial centers.

This paper, as part of the ongoing research project Sustainability on the Edge, seeks to understand the challenges of these dual and complex competences from the point of view of the island community. We conducted seven hour-long ethnographic interviews with community organizers from Barra and here we present excerpts from interviews with Sheena, Neil, Catriona and Iain ${ }^{1}$ They all live on Barra and are involved in political, communal and entrepreneurial activities and hold, or have held, some kind of institutional or semi-institutional responsibility over the local management of resources. They are thus highly visible in island life as well as to outsiders, such as funders and governmental bodies, for whom they represent the periphery. In the interviews these community organizers have identified communication between actors as an issue of key concern and there is a feeling that their voices are not heard by outside regulatory bodies of governance with differing understandings of sustainability. In the terms of this paper, whose voices get heard (and whose do not) depends on the scale at which sustainability gains meaning.

Sustainability, both in its environmental and economic sense, is a key idea in recent policy making. As an 'empty signifier' (Laclau, 1996) its meanings and connotations are fought over by an array of social, political and economic interests (Brown, 2015; Bartlett, Montesano Montessori, \& Lloyd, in press). Sustainability is usually evoked to respond to the perils of climate change and the far-reaching

1. All names have been anonymized. We thank Marta Wilczek-Watson for transcribing a number of interviews. 
social effects of globalization, particularly in its current neo-liberal manifestation. At the governmental level sustainability can be regarded, we suggest, as part of a set of soft-power policies that wield control through co-opting and influencing public opinion rather than through hard-power policies of coercion through military might or economic pressure (cf. Nye, 2004). Sustainability policies promote the protection of species and habitats, encourage the local management of resources and generally operate within an environmental discourse that seeks to harmonize human civilization with nature for now and for future generations while ensuring economic development (cf. Munasinghe, 2009).

Our interviews suggest that islanders share such a view of sustainability, but that the perspective at the local scale fosters significant differences in terms of what aspects are more pressing and salient while first-hand experience underpins different understandings of the local socioeconomic and cultural ecology. In general, islanders view sustainability first and foremost in terms of the continuance of the island community and the economic conditions that will enable this, such as job security, good transport and telecommunication links, education facilities and efficient use of land and resources. What counts as sustainable on Barra, it seems, connects to a discourse of hard-power economic pressures and provision of essential infrastructures. These competing perspectives can be traced throughout our research as the tensions between soft-power environmentally 'healthy' growth and hard-power economic survival are negotiated through the construction of a voice that at once indexes local legitimacy and worldly knowledge. We employ scales as a way to discuss such complex indexicality in the community organizers' voices.

\section{Scales, indexicality and voice}

The notion of scales, borrowed from human geography, political philosophy and history, entered sociolinguistics to make one crucial point: meaning and power is contingent on multiple, yet ordered, contexts. In this sociolinguistic usage scales are evoked to account for - rather than reduce - the complexities of contexts in times of globalization (Blommaert, 2007, 2010, 2015, 2016; Blommaert, Collins, \& Slembrouck, 2005; Blommaert \& Rampton, 2011; Blommaert, Westinen, \& Leppänen, 2015; see also papers in Collins, Slembrouck, \& Baynham, 2009; Canagarajah \& De Costa, 2016; Singh, Kantara, \& Cserző, 2016).

What particular utterances or signs mean, we know, depends on the context in which they are uttered (Silverstein, 1976), while, conversely, it is through signs that contexts themselves are constructed (Gumperz, 1982). These two semiotic dimensions, context dependency and contextualization, are conceptualized as indexicality (Silverstein, 2003). Scales, then, force us to appreciate that these 
indexicalities always operate on many, yet ordered, levels of meaningfulness. This indexical ordering constructs voice contrasts and speakers seem to recognize that some voices are more powerful, or carry more prestige, or can better claim authenticity than others. High varieties (Ferguson, 1959), elaborated codes (Bernstein, 1971) or professional registers (Agha, 2005) usually have the capacity to index such higher-scale voices. They circulate more widely than local vernaculars and are thus understood, or so it is proposed, by a wider or more important audience. Yet, in a particular ethnographic setting vernacular voices can become valorized as prestigious and can index higher scales of power and meaning in local sociolinguistic life. Focusing attention on how speakers move across and between scales (upscale, downscale, outscale, rescale, jump scales, etc.) can help us appreciate that scales are not immutably fixed and that a voice that carries prestige at a higher scale is not always more powerful at a lower scale.

A scale, although readily imaginable as a spatial category, also involves time or history as well as personhood or identity. We can thus think of a scale as a spacetime-identity nexus of meaning, a Bakhtinian chronotope that can be evoked to establish and negotiate the power and meaning of a particular voice (Bakhtin, 1981; Silverstein, 2005; Agha, 2007; Perrino, 2015; Blommaert, 2015). Congruently, Agha (2007: 321) defines a chronotope as a "semiotic representation of time and place peopled by certain social types". In the standard view, longer, larger, more permanent, global, generalized and abstract chronotopes can be regarded as indexing more power than shorter, smaller, more momentary, local, particular and concrete chronotopes. From this perspective, the notion of chronotope as unified spacetime (see also Wallerstein, 1997) implies that an increase across the spatial dimension entails a parallel increase along the temporal dimension. Our data, however, suggests that extensions of time and space, the respective powers of chronos and topos, can be discursively construed in more complex ways. While the terrestrial centers can be imagined to govern vast geographical areas, such as nation states, and thereby inhabit power as topos, their histories and temporal power can be argumentatively constructed as shallow in comparison to the deep history of island life, which inhabits power as chronos. Rather than understanding everything that is spatially larger as also being temporally more extensive, or vice versa, we thus need to pay attention to how speakers negotiate chronos and topos and make them operate on distinct yet highly interconnected tiers, on which they can be scaled up and down.

In the current phase of globalization, we can expect considerable complexity of such negotiation across and between scales: the local and global influence each other in complex ways, histories intersect and diversity itself becomes diversified (Vertovec, 2007). For peripheries especially, the complexities of globalization create both uncertainty and possibility in the interplay and negotiation of scales. With the unprecedented intersecting of cultural possibilities, new inequalities become 
significantly articulated and visible. A scalar perspective of discourse acknowledges, therefore, that power and meaning are polycentric, or negotiated in relation to various and shifting centers of normativity (Blommaert, 2010).

\section{Scale uncertainty in times of devolution}

While globalization tends to centrifugally diversify the resources of meaningmaking, the current political climate also seems to emphasize the nation-state as the centripetal locus of meaning. We seem to witness a return to national essentialism that Beck (1994) understood as a reflex of modernization. In the case of Barra, the current moment of globalization is perhaps most clearly manifest politically in the policy of devolution. Over the last 40 or so years, the peripheries of the UK, the socalled Celtic Fringe, have gained some political autonomy from the central UK government in Westminster, London. Scotland is arguably the most devolved nation within the UK, with its own government, limited tax-raising powers, and control over a number of institutions at the national (i.e. Scottish) level. In September 2014 the Scottish Government held a referendum on full independence from the UK. Approximately 44 percent of voters voted for independence and approximately 56 percent voted against it. Two years later, in June 2016, the whole of the UK held a referendum that will lead to Britain's exit from the EU, the so-called Brexit. Because Scotland voted predominantly against Brexit, the Scottish Parliament has officially requested a second referendum, which would make it possible for Scotland to remain in the EU if it gains independence from the UK. This presents remarkable conflicts of interest as the population of Barra voted $70 \%$ in favor of independence, yet the fishing industry, both locally and in Scotland as a whole, is very skeptical about EU policy, with national organizations supporting Brexit and the Western Isles as a whole voting 53\% against independence - but also 55\% against Brexit. Our interviews were conducted in late 2015 and early 2016, a year after the Scottish independence referendum in September 2014 and just months before the UK-wide referendum on EU membership in June 2016. The interviews, as well as our analysis, thus capture a moment in which Scottish politics is characterized by a heightened awareness and uncertainty about the scales on which Scotland, as well as its internal peripheries, will operate in the future.

This uncertainty provides possibilities for rescaling and imagining new types of devolution for the peripheries: from Westminster to Edinburgh, from Edinburgh to the Western Isles and from the seat of the local council in Stornoway, on the island of Lewis, to Barra. This system of UK-internal devolution is part of a larger European and international network of supra-governmental institutions such as the EU, several transatlantic unions, global interest groups and international regulatory bodies such as the International Monetary Fund. Political action at any 
of these levels of governance needs to take into account the higher-level scales of governance, as well as the lower scales, in which it operates. The centers thus each have higher centres in relation to which they might occupy a peripheral position and these peripheries have their own peripheries and so on, creating a kind of fractal scalarity that Westinen (Blommaert, Westinen, \& Leppänen, 2015) has also described for the ideological topography of Finnish hip hop (see also Brenner 2001; Baynham, this issue).

Such scalar topographies, we need to remember, are not fixed but constantly in flux, and especially so in times of heightened scale uncertainty. These flows of scales offer up opportunities for rescaling. For instance, after the Scottish independence referendum in 2014, the three island councils of Scotland, Orkney, Shetland and Western Isles, put forward a collaborative vision - Our Islands, Our Future to respond to the challenges faced by the peripheral island communities, ecologies and economies within the many changing levels of governance. Such collaborative endeavors create centers within the peripheries, to increase their visibility and attract funding from the higher-scale centers: from Edinburgh, from Westminster, from Brussels, and from other global agencies. This leads to an extremely complex network of allegiances that cross-cut the fractal scalarity and potentially bypass hierarchical levels of governance, as when the EU directly funds projects in Europe's peripheries without necessarily negotiating with governments in the capital cities (Bachtler \& Turok, 1997).

In the following analysis we will show how community organizers navigate these scales to make powerful arguments in the context of our interviews. First we show that our interviewees recognize scales. Scale is thus not only the researchers' category through which we subject our participants' talk to conduct close data analysis informed by globalization research but also a category with which our interviewees make sustainability meaningful for Barra. Secondly, we show how our participants jump between scales, how they rescale, to make arguments that carry their voices across scales. Finally, we turn our focus to informal types of community organization as a possible alternative to more formal types of community organizing.

\section{Recognizing scales}

In many of our interviews ideas about the scales of governance as well as the cross-cutting characteristics of scales are recognized and discussed. In this first interview excerpt the recognition is based largely on an insider/outsider dichotomy. Sheena, a community organizer who supports the production and sale of local goods, regrets that representatives of outside bodies who come to Barra to promote sustainability do not listen to the local people but rather impose their 
predefined ideas of what is good for the island. Transcription conventions can be found in the appendix.

\section{Excerpt 1.}

962 Tom: how'd that look then if they were to do work with [( (Local Organization)) ?

963 Sheena: [I think they would have to

964 come in and they'd have to listen to people before they say anything (.) just

965 listen about what people's priorities are and then work out how they can help

966 as opposed to putting stuff on the community

967 Tom: uhum uhum

968 Sheena: you know and it could be that what they want and what the community wants

969 are actually very similar

970 Tom: uhum

971 Sheena: but there's always this there's gonna be this tension and the spite (.) if they

$972 \quad$ just come and just listen

973 Tom: uhum

974 Sheena: you know and listen to what the community wants how the community wants

975 to develop and grow and whatever then it could be there's really good tie-ups

976 there

(Sheena, interview, lines 962-976)

Sheena linguistically indexes the outsiders' voice by using the third-person plural shifter 'they'. The anaphora (cotextual referent) of this 'they' can be found a few lines before Excerpt (1) sets in. There Tom mentions the "government and European organizations" that are "working much like they already know the answers". Thus Sheena's instances of 'they', as well as Tom's "they" (line 962), in Excerpt (1) seem to index actors on higher levels of governance that, and this is perhaps the crucial bit, operate in opposition to the islanders. Her rather clear-cut indexical distinction between insiders ('people', 'community') and outsiders ('they') asserts that this distinction could lead to tensions if the outsiders put their own ideas first and do not listen to the islanders. For her, overcoming the tensions can be achieved through a fair-minded mode of communication, a dialogue, between the outsiders and insiders. Outsiders should first "listen to" (line 964) the local community before making suggestions, scaling back the aims they had already identified in the larger scales of institutional protection. In this way they can enter into an equal conversation with the islanders, who have valuable local knowledge and expertise that needs to be 
taken into account (cf. also Bartlett 2012 on the downscaling of specialized knowledge to make it relevant to local issues). As both sides work towards a shared and viable vision of sustainability a common ground of interests, "really good tie-ups" (lines 975-976), and viable solutions for the future could be developed. While this surely questions who is expert and who is not, Sheena's expectation also reinstates and thereby recognizes the outsiders' power. They have the choice over listening or not listening and they seem to have more often chosen not to listen and just impose their ideas of what is good for the island community.

This power of the outsiders, however, is challenged in Sheena's argument. From her perspective the equally important voice of the islanders needs to heard in a fair-minded dialogue. For this argument to take effect, Sheena construes a unified island voice, as suggested in her "what the community wants how the community wants to develop and grow" (lines 968-969). Sheena's univocal depiction of the Barra community becomes meaningful through the indexical distinction between insiders and outsiders. This distinction situates the Barra community in relation to larger-scale actors who are involved in development and sustainability policies and come to the island to protect and manage. Vis-à-vis these outsiders, the Barra community needs to articulate a clear, singular voice that can be recognized by the outsiders and enter into an equal dialogue with them.

If we move down scales, the singularity of the Barra voice loses its meaningfulness and gives way to polyvocality and internal complexity. Neil, who is involved in both the fishing industry and local activism, suggests that the Barra community in fact consists of a multitude of communities, each with their own interests. Upon being asked about his role as a community development officer, he says that he was:

\section{Excerpt 2.}

95 Neil: working with (.) a whole different kind of (.) I suppose the communities within the community (.) just you know (.) the different groups within the community each which (.) feels that it's got a a an interest of its own (.) so you had for instance uh ((Local Organization 1$)$ ) the ((Local Organization 2)) (.) you had ( Local Org Organization 4)) (.) uh 
The singular voice we encountered in Sheena's description of outsiders and insiders above, here gives way to a polyvocality of insider voices, represented through several local organizations (anonymized in the transcript) that are, however, all part of "the bigger picture" (line 101). The fact that there are many communities within the Barra community suggests that it is rather difficult for outsiders to identify who to speak to and listen to on a particular topic. The Barra community itself is polycentric and complex.

Sheena's and Neil's accounts illustrate that community organizing on Barra involves a polycentric negotiation between macro-forces from outside on the one hand and the micro-cosmos of the island on the other. In both accounts the micro and the macro appear as relatively stable or fixed contexts in which Barra operates. These contexts seem to each fit into a larger context, like a Russian doll.

In Excerpt (3), however, Iain, who has worked for public organization both nationally and in Barra, complicates this picture. Iain speaks about a scalar dilemma that occurred when the Western Isles Council, which is located in Lewis, the largest island in the Outer Hebrides and several islands to the north of Barra, cut the funding for a direct flight between Barra and Stornoway on Lewis. Iain here recounts a story that, as he told Tom, he uses frequently to make the councilors in Stornoway understand the consequences of their cuts.

\section{Excerpt 3.}

553 Iain: but we we $(-)$ know - ) we know that we can get to the seat of our (.) national

554 government er in two and a half hours (.) an hour's an hour's flight to

Glasgow and an hour's bus through to (.) to Edinburgh and we're at the seat of

our national government (.) erm our seat of our local government (.) would

557 take us about six seven eight hours to get up to

558 Tom: since they cut that plane

559 Iain: since they cut that plane

560 Tom: da@e@e@

561 Iain: so we use that all the time now (-) and it really annoys them you know :- a

562 (.) but er it does kinda bring it home a wee but you know like ((whispering))

563 "oh right enough" I mean it's maybe not too it's maybe not too relevant cos

564 you probably get to (1.0) parliament and find out nobody's there but

565 Tom: () at least you get a weekend in Edinburgh $($ ) 


\section{Iain: yeah that'll be good \\ 567 Tom: () better than a weekend in stornoway () (Iain, lines 553-567)}

Iain's story suggests that the hierarchical order of governance (World $>$ Brussels $>$ Westminster $>$ Edinburgh $>$ Stornoway $>$ Barra) is not always in order. In this example Stornoway cut itself off by cutting the direct air link from Barra (line 558-559), so that Barra folk can now reach Edinburgh much faster than they can reach Stornoway (line 553-557), effectively bypassing the council-level of governance and metaphorically rendering it as unimportant. Iain's story is taken from an ongoing dialogue with councilors in Stornoway and retold and recontextualized within our research interview. It is a repeatable story of some emblematic value that can be used "all the time" (line 561) in order to talk about scalar complexities of acting in the peripheries. The bypassing of the council-level of governance is but a minor disruption to the established order but carries, we suggest, the threat of further insubordination. Iain also emphasizes a more general disillusionment with politics by moving back into the story world to suggest that national Scottish parliamentarians will probably be absent in any case (line 564), which then expands into a more humorous exchange with Tom about at least getting to spend some recreational time in Scotland's capital.

In Excerpt (4), Catriona, who is very active in lobbying national bodies, suggests that this cross-cutting of scales also works the other way around, from the macro to the micro, again rendering the local council as unimportant or even redundant.

\section{Excerpt 4.}

410 Catriona: I think part of the reason for that it maybe EU (.)
uhm led as well I'm not
entirely sure but so much funding has suddenly
become available for locally
based community projects (.) so if you're looking
what we've got in Barra (.)
we've got (.) we've got all sorts of organizations
that are tapping into funding
and you you look at the community council and you
think (.) "well what is
$415 \quad$ there left for them to do?"
(Catriona, interview, lines $410-415)$

The council in Stornoway, as well as in fact the Scottish Government and the UK Government, are seemingly bypassed by direct funding streams from Brussels or similar larger scale centers. Catriona's hedges and her careful epistemic stancetaking, "I'm not entirely sure but..." (lines 410-411), generalize and upscale the outside levels of governance and funding. In her account it remains implicit 
where the funding comes from, why it is distributed and who has an interest in supporting and helping. What is clear though is that money becomes available "suddenly" (line 411) from the higher scales and that this has consequential effects on local governance. Catriona stresses later in the interview that she supports the direct funding from larger-scale bodies to local organizations, but also suggests that these local organizations need to encourage local participation to become accountable and open to democratic scrutiny.

In the four excerpts discussed so far, we have shown that community organizers on Barra recognize higher scales of power that operate on some kind of general level of governance that is not fully transparent in their accounts. They also operate in opposition to the island community, which is in itself polyvocal and can cross-cut scales. In the second part of our analysis we show that community organizers, because they are aware of the polycentricity of their work and understand how the different scales are ordered, develop strategies to find new possibilities of making their own voices heard, especially in times of devolution and its heightened scale uncertainty. We suggest that these voices are constructed through processes of upscaling.

\section{Upscaling communication}

One of the most unmistakeable instances of upscaling in our data can be found in the interview with Sheena. Sheena recognizes that the language of the formal institutions, what she calls "civil servant speak" (line 943), needs to be actively appropriated for the local community organizers to access funding. Sheena recounts a story in which she applied to a national trust for funding for her social enterprise. She was unsuccessful in the first year but then changed the name of her social enterprise to give it a more 'social' ring and received funding in the second year.

\section{Excerpt 5.}

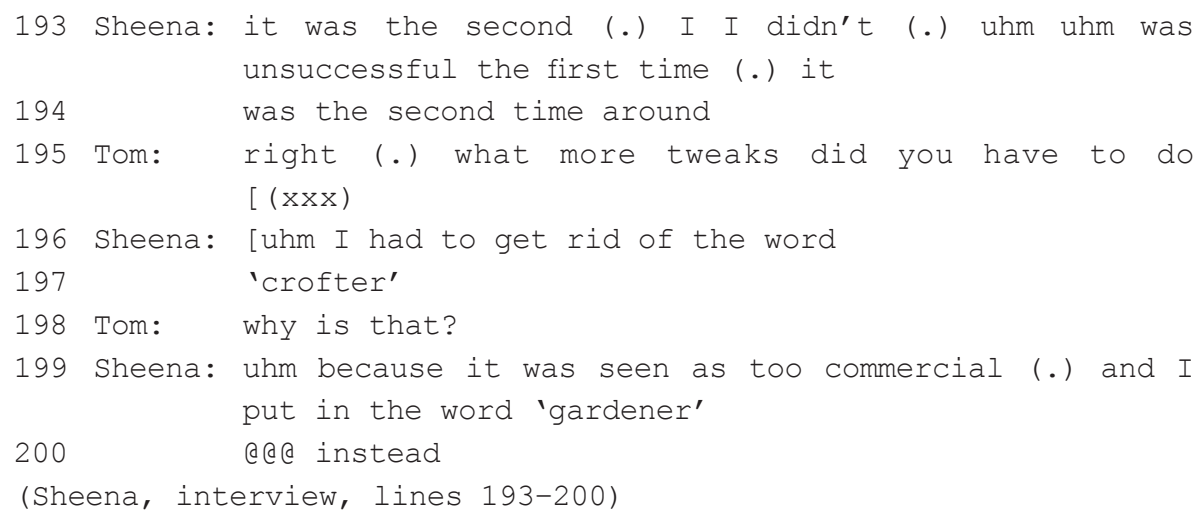


The name change from 'crofter' to 'gardener' was a way for Sheena to tap into funding as well as to sharpen the profile of the goals of her enterprise within the formal structures of funding and national policies. The name change draws attention to Sheena's metalinguistic awareness of how linguistic signs, in this case the lexical items 'crofter' and 'gardener', can index different discourses that are connected with commercial and social types of enterprise respectively. This semantic contrast employed, while effective for funding purposes, is rather nonsensical at the local scale, however, and the humor of the situation arises out of an awareness of both this lack of fit and the canniness of the community in exploiting it. Although crofting does involve stockbreeding and the sale of surplus produce, the term 'crofter' evokes notions of self-sufficiency, land ownership and social organization rather than commercial profitability. However, for outsiders, Sheena says, "it was seen as too commercial" (line 199) while the term 'gardener', though a long way from how the communities might describe their activities, gained acceptability. Sheena is aware of the indexicalities and reimagines island activities from the viewpoint of the funding agency and so renames her proposal to attend to the norms of the higher-scale centers. Even though Sheena goes on to say that the organization from which she accessed funding shifted their policies slightly so as to appreciate more commercial projects as a viable route to sustainability, the change from 'crofter' to 'gardener', we suggest, is a type of linguistic upscaling that illustrates the community organizers' awareness and navigation of multilevel governance.

The signifier 'crofter' to mean small-scale farming is restricted to the Scottish Islands and Highlands and therefore clearly indexes a rootedness in the local. Because crofting is becoming less important on Barra - some say it is dying out - it also indexes historical or nostalgic ideas of what the island life used to be like. The signifier 'gardener', in contrast, seems to index a modern, even urban, sentience of what it means to promote healthy lifestyles, sustainability and community cohesion in late capitalism (Okvat \& Zautra, 2011). The juxtaposition of these two worlds, and the movement of the islander between them, is a common source of humor in stories and songs in the Highlands and Islands.

The complex timespace intersections involved in this linguistic upscaling from crofter to gardener reveal the polycentric orientation of community organization on Barra and Sheena's laughter (line 200) after she mentions the word 'gardener' might indicate her metalinguistic awareness that her upscaling is perhaps irrelevant to the central aims of her project or for the island community. The renaming of her project seems to be 'just' linguistic, but it is at the same time necessary for her strategy to make her project understood and eligible to funding from higher-scale centers.

In similar ways Iain describes the term 'social enterprise', which we suggest bears traces of indexicalities comparable in certain ways to the term 'gardener'. 
In official terminology, a social enterprise commits to a mission that reinvests in the community and in the environment from which it gains its profits, rather than channeling the profits into the pockets of capitalists and their institutions (cf. <socialenterprise.org.uk>; Dart, 2004). A social enterprise, therefore, seems to occupy a middle ground between a not-for-profit organization and a fully profitable business and might thus be regarded as a good compromise between the outside's soft-power environmental and the island's hard-power economic understandings of sustainability.

However, despite this apparent fitness for local purpose, the foreignness of the term is a potential problem. In Iain's words, 'social enterprise' is "a term that's come down over the last few years (.) and you're tryin to slot things into that term (.)" (Iain, interview, lines 201-202). Iain here recognizes 'social enterprise' as a recent phenomenon that was generated outside, and in some ways higher up in scale terms, that has "come down" to the island. He furthermore recognizes that this term is an empty signifier which can be filled with a host of local meanings as appropriate.

Iain continues to argue that although local people on Barra seem to be unfamiliar with the specific term 'social enterprise' and its socio-political indexicalities, they nevertheless recognize that certain soft-power agencies, like the local newspaper Guth Bharraidh (The Voice of Barra), indeed contribute to the hardpower economy of the island.

\section{Excerpt 6.}

202 Iain: but it's there's been a lot of social ent- listen if you ask people in Barra "who

203 what's a social enterprise" they would probably say "well I haven't got a clue

204 what you're talkin about"

205 Tom: yeah de

206 Iain: but then again if you say "well the Guth Bharraidh has been runnin for thirty

207 five years" and they say "ah yes I know it's a great service" and it's like and

208 it's enterprising and it makes a profit (.) you know and it kind of helps

209 employing people

210 Tom: aha

211 Iain: and so so it is an enterprise and if that's what they want to call it

(Iain, interview, lines 202-211)

The final "they" (line 211), similar to Sheena's use of 'they' in Excerpt (1), refers to a higher-scale agent that can impose certain terms, like 'social enterprise'. Such 
terms are not readily understood or necessarily deemed significant by the islanders (lines 203-204), though it is understood that a soft-power community newspaper can indeed be economically profitable, provide great services and also exist over large periods (lines 206-209). Iain, we should note, here takes for granted that the social aspects of the Guth Barraidh will be readily understood and so emphasizes its entrepreneurial benefits, such as "service" (line 207), "profit" (line 208) and "employing people" (line 209). This emphasis, he argues, helps islanders understand that the incoming term imposed from above does not in fact mean anything different to what has been going on locally anyway. A social enterprise is thus not necessarily a fundamentally new way of enterprising sustainably but rather an empty signifier that can be put to service to upscale community voices, to enable them to be heard within higher scales of institutional funding.

Another way for community groups to make themselves visible to potential outside funders is to form constituted groups or small formal organizations. However, our interviewees were sceptical of the representational legitimacy of such constituted groups. Even if these groups showcase themselves as official representatives of a specific community, topic or issue, they often lack a systematic agenda, according to Catriona.

\section{Excerpt 7.}

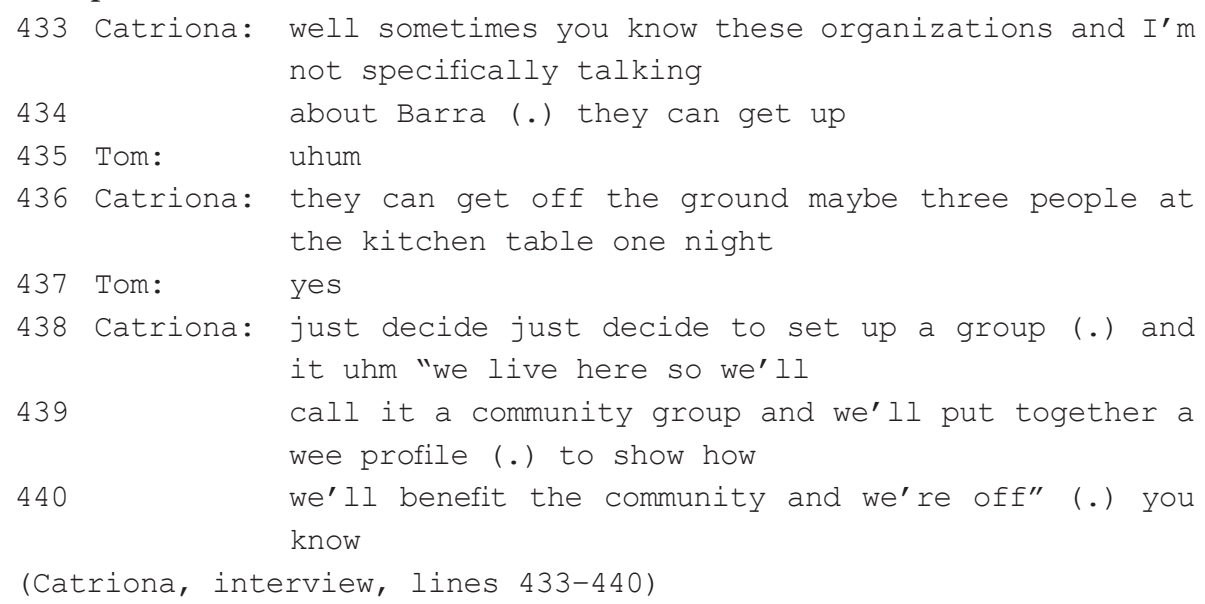

Catriona's hedging "I'm not specifically talking about Barra" (lines 433-434) frames her as someone with translocal experience. From this experienced positionality, Catriona's argument operates on a higher scale to evaluate such 'organizations' across the islands. The narrated scene at the kitchen table one night then downscales her argument and through the juxtaposition of higher and lower scales creates incongruence and humor (cf. Attardo and Raskin, 1991) in the interview context. The three narrative figures decide, just on the basis of living on whichever 
island it may be, to "call" (line 439) themselves a "community group" (line 439), which, through a performative speech act of naming, describes a shift towards formalization. The "wee profile" (line 439) they put together then publicizes and circulates the agenda of the formalized group across scales and frames it as charitable in order, we are left to assume, for the group to access funding.

Neil expresses a similar concern in the following excerpt.

\section{Excerpt 8.}

416 Neil: and one of the things that that bothers me about this whole thing is that (.) it is

417 a perception (.) that people who come from that background $<$ the background

418 where it's absolutely normal to have> constituted groups coming into a

419 community which has a much mo- more flexible way of working (.) can

420 effectively turn around and say (.) "we're gonna hold a meetin (.) in the hall (.)

$421 \mathrm{u}: \mathrm{h}$ or in a hall or in our building" <or whatever the hell> "uhm and we're

422 going to fo:rm the justice and peace committee" for the sake of any argument

423 (.) right (.) "a:nd after we've done that <and anybody could come along and

anybody could be elected onto the board> (.) alright a:nd then and we'll get it

all goin and then that's (.) and that's we're gonna look after (.) justice and

peace" (.) a:nd you're gonna go "well look" a community that's foreign to

you just sits back and goes "what's happened?"" (.) uh uh uhm (.) but

suddenly you got somebody (.) who (.) may not represent anybody at all (.)

429 other than the people who turned up at that meeting

430 Tom: yeah and and they're constituted

431 Neil: and they're constituted and they can go "look well we're a constituted group

432 from Barra (.) and we are recognized" and there may not be a Barrach ${ }^{2}$ among

2. Barrach, in Gaelic, means a person from Barra. Note, in the second occurrence of the term (line 435) the plural is Anglicized, so rendering the term locally-indexical English. 


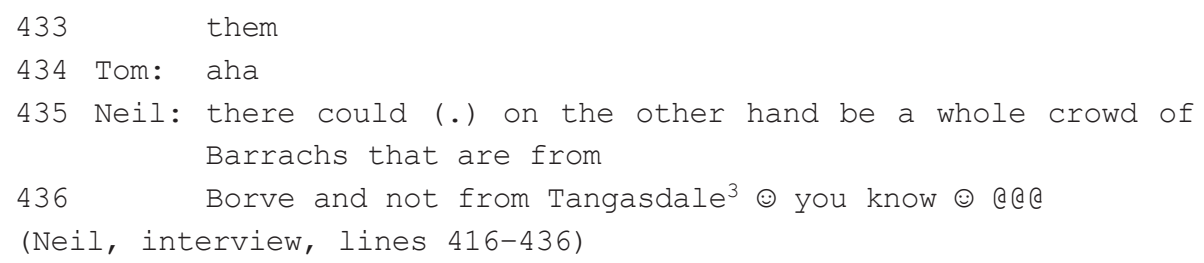

Neil here expresses the concern that people who come from a background of community organization form constituted groups in order to represent the island community, which, in his phrasing "has a much mo- more flexible way of working" (line 419). These people are not necessarily outsiders but could well be any of the islanders who decide to go down the more formal way of community organization and perhaps access national or EU funds. In Neil's account the procedures that are required to formalize community organization, namely the procedures involved in forming constituted groups, holding formal meetings, electing members, are potentially ineffective as they do not necessarily represent the island adequately (lines 427-429), either because no one who constituted the group was actually from Barra, a Barrach, (lines 423-433) or because everybody who constituted the group was from one particular village and not from another (lines 435-436). In Neil's argument the potential problem of representation of constituted groups is a function of the scales from which they gain their representational legitimacy: the scales are either too small (one village) or exogenous (outsiders).

If the complex scalar rearrangement involved in formal organization is dilemmatic, as Sheena, Neil, Iain and Catriona suggest, what then are the alternatives? What is the island's "more flexible way" that Neil mentioned? In the final analytical section we explore how our interviewees understand sustainability from a point of view that we describe as informal types of organization.

\section{The complexity of informal organization}

With our deployment of the notion of informal organization we broadly follow discussions of the informal economy (Castells \& Portes, 1989) that seek to account for the complexities of the modes of production in late capitalism, both in the peripheries and in the centers of capital. Inspired by this line of research, we do not want to suggest any kind of lesser or less complex formality in the local organization of Barra. We even stress that local organization in the peripheries is more complex than in the centre, due to the dilemmatic upscaling negotiations that the periphery is forced to develop vis-à-vis the centre. Informal types of organization

3. Borve and Tangasdale are two small villages on Barra. 
are thus more complex and elaborate than formal types. This is so, because informal organization partly depends on formal organization, which makes funding, circulation and recognition possible, but it needs to downscale this formality so that it becomes legitimate and authentic in relation to the rootedness of the community one wishes to support or represent. On Barra, the flexibility of community organizing has a long and successful history, as described in the introduction above, and in this final section we show that the mechanisms of such organizing are understood by our participants as being at once informal and deeply rooted historically.

Neil offers the example of the Fisherman's Mass, an annual event that takes place on the pier in Castlebay $<$ https://www.youtube.com/watch? $\mathrm{v}=\mathrm{d}$

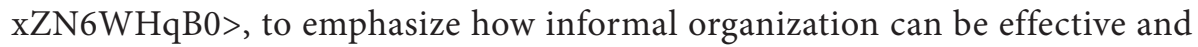
efficient.

\section{Excerpt 9.}

346 Neil: yeah I mean like (.) there're (2.0) again I I can give you another GREAT

347 example of it is (.) the effort that's put in for the Fisherman's Mass

348 Tom: aha

349 Neil: as far as I'm aware there has never been a committee (.) for that $=$

350 Tom: =right

351 Neil: uh it (.) there's not a formal organization (1.0) to run something which is one

352 of the most ORganized events (2.5) it's

353 Tom: () himself upstairs is organizing it () adada

354 Neil: ade (.) well yeah (.) when you look at it how it comes together (-) (1.5) it's

355 (2.0) by (.) a lot a hard work (.) by (1.5) a hell of a lotta folk (1.5) most of

356 whom only find out how they're doing it ae (-) a day or two in advance (-)

(Neil, interview, lines 346-356)

Neil's account of the Fisherman's Mass emphasizes the spontaneity and informality with which organization takes place and has taken place ever since. He says that there has never been a formal committee to run a very well-organized event (line 349, lines 351-352). But who/what then runs this event? Tom humorously offers God - "himself upstairs" (line 353) - as the highest-scale grand designer of the Fisherman's Mass. Neil takes up the humor (line 354), but then more seriously proposes a set of traditional island values: hard work, a dense network of familial and social ties, and a communal spirit of spontaneity (lines 355-356). These types of resources derive from historical and traditional knowledge of how to get things 
done locally, rather than from specialist knowledge generated formally through constituted groups.

Sheena, similarly, highlights that "the fishermen that fish in these waters for all their lives, they are more expert than people that come down discover something like 'Oh wow let's protect it'" (Sheena, interview, lines 786-789). Who is expert and who is not, in this argument, depends on traditional and holistic knowledge that was handed down from generation to generation and the lifelong experience of locals, rather than the specialist knowledge from the outside, which, as she says later, has a "focused viewpoint cos they've got their project and job it's a nice nice little box" (Sheena, interview, lines 917-918). The fishermen's life-long historical knowledge is here juxtaposed with the tick-box knowledge of short-term intervention projects. Sustainability is therefore understood on two different chronotopic scales. The fishermen have larger time scales at hand, but are restricted to the local; the outsiders have more translocal knowledge and recognition, but they lack drastically in temporality (see also Bartlett, Montesano Montessori, \& Lloyd, in press).

In the introduction we described the histories of Barra not merely to situate our object of research in time but also to point to the deep historical archive of which people on Barra perceive themselves to be part. We can see from Sheena's and Neil's accounts in this section that sustainability is a historicized notion that is contingent on the past knowledge that was informally handed down from generation to generation and circulates as part of a profession and lifestyle. We would like to highlight therefore that sustainability on the island is understood by our participants as operating on large timescales (cf. Braudel, 1973). The island's deep-historical sustainability contrasts to some degrees with the ways in which sustainability is promoted and executed politically by states, non-governmental institutions and other formal agencies operating on higher levels of governance (see also Singh \& Dattatreyan, 2016). Here, sustainability resembles a short-term intervention (e.g. a three-year funding project) that would need also to produce immediate effects or at least showable outcomes ('ticking the boxes'). Ironically, even if such higher-scale institutions arguably envision sustainability as generating long-term shifts, the level of governance on which they operate only seems to afford short-term cultural interventions that are intertwined with a progressive logic of what it means to be good in late capitalism.

\section{Conclusion}

In our analysis we first showed how community organizers recognize a difference between the voice of outsiders who come to Barra to protect and help on the one hand and the voice of islanders who live and work on Barra on the other. They also 
recognize that these two voices are not singular but complex, even if they generally assign some kind of formality to the outsiders' voices and some kind of informality to the islanders' voices. We then traced how the multitude of voices on Barra are organized or formalized through upscaling so that they can enter and map onto higher-scale centers to access resources provided by outside bodies of governance and funding. Finally, we discussed how informal types of organization are imagined to operate on long timescales that historicize community organization in order to seek legitimacy on a locally meaningful scale.

Community organizers on Barra seem to recognize multiple centers of decision making that operate on different, and at times conflicting, scales of time, space and personhood (chronotopes). The larger terrestrial centers are imagined to require formal discourses, whereas the smaller maritime centers of the island communities seem to organize themselves informally, even if they depend on funding and resources from the larger centers. We hope it has become clear from our analyses, first, that community organizers recognize these scales of formality, and secondly, how they upscale and downscale their communication to make constructive arguments about the sustainability of Barra in the interview context (including narratives of similar rescalings in other contexts). These two dimensions, recognition and rescaling, we argue, construct a voice that is at once informal, emphasizing a historical and experiential quality of what it means to live on Barra, and formal, inflecting this quality with worldly and upscaled knowledge that enables access to dispersed governmental, civic and commercial bodies and so recenters Barra at the intersection of these latterday virtual trading routes.

\section{References}

Agha, A. (2005). Voice, footing, enregisterment. Journal of Linguistic Anthropology, 15(1), 38-59. doi:10.1525/jlin.2005.15.1.38

Agha, A. (2007). Recombinant selves in mass mediated space-time. Language \& Communication, 27(3), 320-335. doi:10.1016/j.langcom.2007.01.001

Attardo, S., \& Raskin, V. (1991). Script theory revis(it)ed: Joke similarity and joke representation model. Humor, 4(3/4), 293-347.

Bachtler, J., \& Turok, I. (Eds.). (1997). The coherence of EU regional policy: Contrasting perspectives on the structural funds. London: Regional Studies Association.

Bakhtin, M. M. (1981). Forms of time and the chronotope in the novel: Notes toward a historical poetics. In M. Holquist (Ed.), The Dialogic Imagination: Four Essays, 1895-1975) (pp. 84-258). Austin, TX: University of Texas Press.

Bartlett, T. (2012). Hybrid voices and collaborative change: Situating positive discourse analysis. London: Routledge.

Bartlett, T., Montesano Montessori, N., \& Lloyd, H. (in press). Contesting key terms and concepts in the civil sphere. In P. Garret \& J. Cots (Eds.), The Routledge handbook of language awareness. London: Routledge. 
Beck, U. (1994). The reinvention of politics: Towards a theory of reflexive modernization. In U. Beck, A. Giddens, \& S. Lash (Eds.), Reflexive modernization: Politics, tradition and aesthetics in the modern social order (pp. 1-55). Cambridge: Polity.

Bernstein, B. (1971). Class, codes and control. London: Routledge. doi:10.4324/9780203014035

Blommaert, J. (2007). Sociolinguistic scales. Intercultural Pragmatics, 4(1): 1-19. doi:10.1515/IP.2007.001

Blommaert, J. (2010). The sociolinguistics of globalization. Cambridge: Cambridge University Press. doi:10.1017/CBO9780511845307

Blommaert, J. (2015). Chronotopes, scales, and complexity in the study of language in society. Annual Review of Anthropology, 44, 105-116. doi:10.1146/annurev-anthro-102214-014035

Blommaert, J. (2016). From mobility to complexity in sociolinguistic theory and method. In N. Coupland (Ed.), Sociolinguistics: Theoretical debates (pp. 242-261). Cambridge: Cambridge University Press.

Blommaert, J., Collins, J., \& Slembrouck, S. (2005). Spaces of multilingualism. Language and Communication, 28(3), 197-219. doi:10.1016/j.langcom.2005.05.002

Blommaert, J., \& Rampton, B. (2011). Language and superdiversity. Diversities, 13(2), 1-22.

Blommaert, J., Westinen, E., \& Leppänen, S. (2015). Further notes on sociolinguistic scales. Intercultural Pragmatics, 12(1), 119-127. doi:10.1515/ip-2015-0005

Branigan, K., \& Foster, P. (2002). Barra and the Bishop's isles: Living on the margin. Stroud: Tempus. Braudel, F. (1973[1949]). The Mediterranean and the Mediterranean world in the age of Philip II, 2 Vols. Berkeley, CA: University of California Press.

Brenner, N. (2001). The limits to scale? Methodological reflections on scalar structuration. Progress in Human Geography, 25(4), 591-614. doi:10.1191/030913201682688959

Brown, T. (2015). Sustainability as empty signifier: Its rise, fall, and radical potential. Antipode, 48(1), 115-133. doi:10.1111/anti.12164

Canagarajah, S., \& De Costa, P. I. (2016). Scale analysis, and its uses and prospects in educational linguistics. Linguistics \& Education, 34(1), 1-10.

Castells, M., \& Portes, A. (1989). World underneath: The origins, dynamics, and effects of the informal economy. In A. Portes (Ed.), The informal economy: Studies in advanced and less developed countries (pp. 11-37). Baltimore, MD: John Hopkins University Press.

Collins, J., Slembrouck, S., \& Baynham, M. (Eds). (2009). Globalization and language in contact: Scale, migration, and communicative practices. London: Continuum.

Dart, R. (2004). The legitimacy of social enterprise. Nonprofit Management and Leadership, 14(4), 411-421. doi:10.1002/nml.43

Ferguson, C. A. (1959). Diglossia. Word, 15, 325-340. doi:10.1080/00437956.1959.11659702

Gumperz, J. J. (1982). Discourse strategies. Cambridge: Cambridge University Press. doi:10.1017/CBO9780511611834

Laclau, E. (1996). Emancipation(s). London: Verso.

Munasinghe, M. (2009). Sustainable development in practice: Sustainomics methodology and applications. Cambridge: Cambridge University Press. doi:10.1017/CBO9780511626777

Nye, J. S. (2004). Soft power: The means to success in world politics. New York, NY: Public Affairs Press.

Okvat, H. A., \& Zautra, A. J. (2011). Community gardening: A parsimonious path to individual, community, and environmental resilience. American Journal of Community Psychology, 47(3/4), 374-387. doi:10.1007/s10464-010-9404-z

Perrino, S. (2015). Chronotopes: Time and space in oral narrative. In A. de Fina \& A. Georgakopoulou (Eds.), The handbook of narrative analysis (pp. 140-159). Malden, MA: Wiley-Blackwell. 
Richards, E. (2013). The highland clearances, 2nd edn. Edinburgh: Birlinn Press.

Silverstein, M. (1976). Shifters, linguistic categories, and cultural description. In K. H. Basso \& H. A. Selby (Eds.), Meaning in anthropology (pp. 11-25). Albuquerque, NM: University of New Mexico Press.

Silverstein, M. (2003). Indexical order and the dialectics of sociolinguistic life. Language and Communication, 23 (3/4): 193-229. doi:10.1016/So271-5309(03)oo013-2

Silverstein, M. (2005). Axes of evals: Token versus type interdiscursivity. Journal of Linguistic Anthropology, 15(1), 6-22. doi:10.1525/jlin.2005.15.1.6

Singh, J. N., Kantara, A., \& Cserző, D. (Eds.). (2016). Downscaling culture: Revisiting intercultural communication. Newcastle upon Tyne: Cambridge Scholars.

Singh, J. N., \& Dattatreyan, E. G. (2016). Cultural interventions: Repositioning hip hop education in India. Linguistics \& Education, 36(1), 55-64.

Stiùbhart, D. U. (2005). Rioghachd nan Eilean: Mile Bliadhna de dh'Eachdraidh nan Gàidheal 550-1550. Dunblane: Clò Hallaig.

Vertovec, S. (2007). Super-diversity and its implications. Ethnic \& Racial Studies, 30(6), 1024-1054. doi:10.1080/01419870701599465

Wallerstein, I. (1997). The time of space and the space of time: The future of social science. <http://www2.binghamton.edu/fbc/archive/iwtynesi.htm> (29 May, 2017).

\section{Appendix Transcription conventions}

(xxx)

((shocked))

(a)

?

[

[]

$=$

underlining

CAPS

$<>$

(:) (:)

:

trunc-

,

“" untimed short pause or end of an utterance

longer, timed pause

indecipherable data with one syllable represented as ' $\mathrm{xxx}$ '

nonverbal, paralinguistic and other contextual information

laughing syllable

rising intonation, possibly a question

start of overlapping speech

entirely overlapped speech

contiguous, 'latched' utterances (no perceptible pause)

perceptible additional emphasis

loud speech

fast speech

smile voice

lengthened syllable

truncated word

intertextual voice

represented discourse (self-quotes and quotes of others) 